\title{
Survival of Curtobacterium flaccumfaciens pv. flaccumfaciens in the soil under Brazilian conditions
}

\author{
Ricardo M. Gonçalves • José M. Soman • \\ Renate Krause-Sakate • José R. S. Passos • \\ Tadeu A. F. Silva Júnior • Antonio C. Maringoni
}

Accepted: 6 March 2018 / Published online: 10 March 2018

C Koninklijke Nederlandse Planteziektenkundige Vereniging 2018

\begin{abstract}
Common bean has a high relevance for the human diet and a significant socio-economic importance in Brazil. Among the diseases that could infect the crop, bacterial wilt is caused by Curtobacterium flaccumfaciens pv. flaccumfaciens (Cff). Few studies have investigated the survival of this bacteria in the soil; therefore, the objectives of this research were to measure the survival period of several Cff strains as free cells in soil under controlled conditions; the survival period of one strain in types of soils with different chemical and physical compositions as free cells under controlled conditions; and the survival period of one strain as free cells in soil under field conditions. In all measurements, bacterial samples were confirmed as Cff using specificprimers by PCR. We observed a difference in the survival period among Cff strains (varying from 22 to
\end{abstract}

\footnotetext{
R. M. Gonçalves ( $\bowtie)$

Instituto Federal de Educação, Ciência e Tecnologia de Minas Gerais (IFMG), Rua Érico Veríssimo, 317, Santa Luzia, MG CEP 33115-390, Brazil

e-mail: rmgoncalves@icloud.com

J. M. Soman · R. Krause-Sakate · A. C. Maringoni Faculdade de Ciências Agronômicas, Universidade Estadual Paulista "Júlio de Mesquita Filho" (UNESP), Rod Alcides Soares, Km 3, Botucatu CEP 18610-307, Brazil
}

\section{J. R. S. Passos}

Departamento de Bioestatística, Instituto de Biociências, UNESP, Caixa Postal 510, Botucatu, São Paulo CEP 18618-970, Brazil

T. A. F. Silva Júnior

Universidade do Sagrado Coração, Rua Irmã Arminda, 10-50,

Bauru CEP 17011-160, Brazil
34 days) and among different soils (varying from 30 to 94 days) under controlled conditions. Under field conditions, the survival period varied from 34 to 80 days as a function of temperature and moisture. These results emphasize the potential Cff survival as free cells in the soil, thereby contributing to the adoption of new management strategies against this disease.

Keywords Ecology $\cdot$ Bacterial wilt · Detection . Phaseolus vulgaris

\section{Introduction}

Bacterial wilt, caused by Curtobacterium flaccumfaciens pv. flaccumfaciens (Hedges) Collins and Jones 1983 (Cff), is a disease with importance in various common bean crops around the world, with the most recent reports from Germany and Iran (Sammer and Reiher 2012; Osdaghi 2014).

The early symptoms in common bean are chlorotic mosaics on leaves, progressing to necrotic spots and wilt, potentially leading to plant death. The disease management is based on the use of certified seeds and resistant cultivars, previous observation of the history of disease occurrence in new planting areas, crop rotation with no hosts species for Cff, incorporation of crop debris in the soil, and eradication of volunteer common bean plants from production fields (Gonçalves et al. 2017; Harveson 2013; Harveson et al. 2005; Osdaghi et al. 2017; Silva Júnior et al. 2012). 
Most of phytopathogenic bacteria do not form spores and resistant structures, which in annual crops means they have to survive between planting cycles associated with infected crop debris and/or in alternative hosts, insects, water, inanimate objects, or soil (Leben 1981; Schuster and Coyne 1974; Vidaver and Lambrecht 2004). The survival period could be influenced by biotic factors such as microbial diversity or abiotic factors such as moisture, temperature, $\mathrm{pH}$, aeration, and chemical and physical soil characteristics (De De Boer 1982; Lennon et al. 2012).

In recent research about the survival capacity of Cff in the soil, the bacteria survived under controlled conditions for a period between 2 to 16 days, being influenced by soil type, moisture, and incubation temperature of the samples (Silva Júnior et al. 2012).

Improving our knowledge about the Cff survival capacity in the soil will allow the adoption of more efficient controlling practices for bacterial wilt management in Brazil and other countries, under similar edapho-climatic conditions. In this context, the aims of this work were: I) to analyze the survival of five Cff strains as free cells in the soil, under the same controlled conditions, II) to analyze the survival of one Cff strain as free cells in six soil types, with different chemical and physical compositions, under the same controlled conditions, and III) to analyze the survival of one Cff strain as free cells in the soil, under field conditions, correlated with climatic data collected during the assays.

\section{Materials and methods}

Location of assays, bacterial strains, growth conditions, and preservation

Assays under field conditions were performed in the experimental area of the Department of Plant Protection (2250'40”S, 48²6'08”W), FCA/UNESP, Botucatu, SP, Brazil. The area has no history of bean cultivation. Weeds present at the location were eliminated by ongoing manual removal throughout the experimental period. All samples were processed in the Laboratory of Plant Bacteriology, Department of Plant Protection, FCA/UNESP, Botucatu, SP, Brazil.

For the survival assays, we used five selected Cff strains Feij. 2500C, Feij. 2628A, Feij. 2716C, Feij. 2772C, and Feij. 2913A, resistant to $100 \mu \mathrm{g} / \mathrm{mL}$ of rifampicin and pathogenic to cv. Pérola of common bean
(Table 1). These strains were obtained from the Laboratory of Plant Bacteriology Culture Collection, FCA/ UNESP. The parental strains were isolated from bean plants showing typical symptoms of bacterial wilt (Table 1), and were cultivated in culture medium supplemented with rifampicin, to selected naturallyoccurring rifampicin resistant strains (Weller and Saettler 1978).

For all assays, the strains were grown in modified nutrient sucrose agar (NSA) culture medium, consisting of nutrient agar (NA; Merck), $5 \mathrm{~g} / \mathrm{L}$ sucrose (Synth), $100 \mu \mathrm{g} / \mathrm{mL}$ rifampicin (Rifaldin), $50 \mu \mathrm{g} / \mathrm{mL}$ thiophanate-methyl, and $50 \mu \mathrm{g} / \mathrm{mL}$ chlorothalonil. All strains were incubated at $28{ }^{\circ} \mathrm{C}$ for $72 \mathrm{~h}$ and for long-term preservation, the strains were grown in the culture medium nutrient sucrose broth (NS) for $72 \mathrm{~h}$, with the addition of $30 \%$ glycerol $(v / v)$, and stored at $-80{ }^{\circ} \mathrm{C}$.

\section{Survival of Curtobacterium flaccumfaciens pv. flaccumfaciens in the soil under controlled conditions}

Two assays were performed under controlled conditions to evaluate if Cff survive and how the survival period is influenced by strain and soil. In assay 1 , the survival of five strains was assessed in soil A (Table 2), and in assay 2, the survival of strain Feij. 2628A was assessed in six different soils. The soil chemical and physical properties are described in Table 2.

For the installation of the two assays, each type of soil was dried separately under greenhouse conditions for 10 days. After, $150 \mathrm{~g}$ of each dried soil were sieved through an 8-mesh sieve (2.8 $\mathrm{mm}$ opening), and transferred to $200-\mathrm{mL}$ polystyrene cups. The soils were infested with $40 \mathrm{~mL}$ of the respective Cff strains $\left(10^{8} \mathrm{CFU} / \mathrm{mL}\right.$; O.D. $\left.550=0.14\right)$, increasing the average soil moisture content to about $20 \%$ (about $67 \%$ field capacity). The cups were sealed with aluminum foil $(15 \times 15 \mathrm{~cm})$ and incubated in a Biochemical Oxygen Demand (BOD) incubator at $20{ }^{\circ} \mathrm{C}$. In assay 2, we performed a correction of the soil moisture level 40 days after infestation, increasing soil moisture to about $20 \%$. The experimental design consisted of a randomized block with 350 cups per treatment. A cup containing $150 \mathrm{~g}$ of soil represented each replication. In each measure, three cups were homogenized or $450 \mathrm{~g}$ of soil per treatment.

To determine the initial Cff population on the installation day, the soil of three cups of each treatment was 
Table 1 List of Curtobacterium flaccumfaciens pv. flaccumfaciens strains used to evaluate the survival period in the soil under controlled conditions

\begin{tabular}{|c|c|c|c|c|c|}
\hline Cff strain & Year of isolation & Sampling place & Bean Cultivar & Colony colour & Rifampicin resistant strain obtained \\
\hline Feij. 2500 & $11 / 13 / 1995$ & Riversul, São Paulo, Brazil & Carioca & Yellow & Feij. $2500 \mathrm{C}$ \\
\hline Feij. 2628 & $11 / 8 / 1996$ & Paranapanema, São Paulo, Brazil & Pérola & Yellow & Feij. 2628 A \\
\hline Feij. 2716 & $11 / 28 / 1997$ & Coronel Macedo, São Paulo, Brazil & Pérola & Orange & Feij. $2716 \mathrm{C}$ \\
\hline Feij. 2772 & 2000 & Paranapanema, São Paulo, Brazil & & Yellow & Feij. 2772C \\
\hline Feij. 2913 & $11 / 20 / 2002$ & Mauá da Serra, Paraná, Brazil & Pérola & Yellow & Feij. 2913A \\
\hline
\end{tabular}

transferred to sterilized 1000 -mL beakers and homogenized to obtain the composite sample per treatment. Isolation samplings were prepared mixing three cups every two days. Ten grams of each composite sample were transferred to flasks containing $90 \mathrm{~mL}$ of $0.005 \mathrm{M}$ buffer phosphate $\left(1.73 \mathrm{~g} \mathrm{~K}_{2} \mathrm{HPO}_{4}, 1.36 \mathrm{~g} \mathrm{KH}_{2} \mathrm{PO}_{4}\right.$, $2000 \mathrm{~mL}$ of distilled water, $\mathrm{pH}$ 7.0), followed by shaking (250 rpm/30 $\mathrm{min}$ ) and resting (30 $\mathrm{min}$.).

The supernatants from samples were serial diluted $\left(10^{0}\right.$ to $\left.10^{-3}\right)$ and $100 \mu \mathrm{L}$ of each dilution were transferred in triplicate to modified NSA culture medium, followed by incubation at $28{ }^{\circ} \mathrm{C}$ for $72 \mathrm{~h}$. In each measure, the moisture of composite samples of soil from each treatment was measured to maintain soil moisture between 15 and $23 \%$. The measures consisted of counting colonies (per plate) that exhibited morphological characteristics similar to those of Cff, numbers were transformed into colony forming units per gram of soil and plotted to construct the survival curve for each survival period. As positive control for each measure, $150 \mathrm{~g}$ of the same soil sampled (without Cff infestation) were inoculated with $40 \mathrm{~mL}$ of Cff suspension ( $10^{8} \mathrm{CFU} / \mathrm{mL}$ of strain Feij. 2628A), followed by processing as previously described. As negative control, soil was infested with the same conditions for positive control, substituting bacterial suspension for sterile water.

Survival of Curtobacterium flaccumfaciens pv.

flaccumfaciens in the soil under field conditions

Wooden frames of a square shape (30 cm length) and spaced $0.5 \mathrm{~m}$ were distributed in an area with red latosol, sandy texture, without previous cultivation with common bean (soil A, Table 2). The soil was infested with $500 \mathrm{~mL}$ of bacterial suspension $\left(10^{8} \mathrm{CFU} / \mathrm{mL}\right.$; O.D. $\left.{ }_{550}=0.14\right)$ of strain Feij. 2628A (which survives for longest periods under controlled conditions). Three assays were installed, namely assay 1 on 16/05/2013, assay 2 on 20/12/2013, and assay 3 on 22/07/2014.

After soil infestation, using polyvinyl chloride (PVC) pipes ( $3 \mathrm{~cm}$ length by $5 \mathrm{~cm}$ diameter), five single soil samples were removed from each wooden frame to obtain one homogenous composite sample. Sampling for isolation was performed every four days, using three composite samples. Ten grams from each composite sample were transferred to flasks containing $90 \mathrm{~mL}$ of

Table 2 Physical and chemical properties of the soils used in the experiments of population dynamics of Curtobacterium flaccumfaciens pv. flaccumfaciens

\begin{tabular}{llllllll}
\hline Soil & Sampling site & \multicolumn{2}{l}{ Soil properties } & & & \\
\cline { 3 - 7 } & & Organic matter $\left(\mathrm{g} / \mathrm{dm}^{3}\right)$ & $\mathrm{pH}\left(\mathrm{CaCl}_{2}\right.$ & Texture & Clay $(\mathrm{g} / \mathrm{kg})$ & Silt $(\mathrm{g} / \mathrm{kg})$ & $\mathrm{Total} \mathrm{sand}(\mathrm{g} / \mathrm{kg})$ \\
\hline A & Botucatu, SP & 11 & 5.3 & Sandy & 139 & 28 & 833 \\
B & Botucatu, SP & 20 & 4.4 & Clayey & 519 & 188 & 293 \\
C & Botucatu, SP & 27 & 5.5 & Clayey & 557 & 308 & 135 \\
D & Botucatu, SP & 29 & 5.7 & Clayey & 492 & 392 & 116 \\
E & Tibagi, PR & 35 & 5.7 & Clayey & 438 & 508 & 54 \\
F & Ponta Grossa, PR & 30 & 5.0 & Medium & 332 & 101 & 567 \\
\hline
\end{tabular}


phosphate buffer, followed by shaking (250 rpm/ $30 \mathrm{~min}$ ) and resting (30 $\mathrm{min})$. The supernatant was serial diluted $\left(10^{0}\right.$ to $\left.10^{-3}\right)$ and $100 \mu \mathrm{L}$ were transferred to modified NSA culture medium, followed by incubation at $28^{\circ} \mathrm{C}$ for $72 \mathrm{~h}$.

The population was measured by counting the colonies that exhibited morphological characteristics similar to those of strain Feij. 2628A until no Cff was detected; all values were transformed to colony forming units per gram of soil. As positive control for each measure, we used $150 \mathrm{~g}$ of the same soil (collected outside the Cff infested area), inoculated with $40 \mathrm{~mL}$ Cff suspension $\left(10^{8} \mathrm{CFU} / \mathrm{mL}\right.$ of Feij. 2628A strain), processed as described previously. As negative control, sample soil was inoculated with $40 \mathrm{~mL}$ of sterile water, instead Cff suspension.

\section{Characterization of bacterial strains}

In all assays, to evaluate the population dynamics of Cff as free cells in soil under field conditions, beyond the observation of bacterial growth in culture medium, colonies exhibiting morphological features similar to those of Cff were selected and identified by polymerase chain reaction (PCR), using the specific-primers CffFOR2 (5'GTT ATG ACT GAA CTT CAC TCC-3') and CffREV4 (5'-GAT GTT CCC GGT GTT CAG-3') (Tegli et al. 2002). Bacterial DNA was extracted following the protocol described in Wilson (2001), and the PCR conditions were according to (Gonçalves et al. 2017).

\section{Climatic data}

Climatic data (precipitation, maximum and minimum temperature) were obtained from a meteorological station positioned $200 \mathrm{~m}$ from the experimental area.

For each measure, we determine the correlation between soil moisture and the bacterial population, using an infrared moisture analyzer (Model IV 2500, Gehaka) three times per sample.

Daily climatic data during the assays were collected and the averages were correlated with the Cff survival period.

Statistical analysis

For the controlled conditions we fitted two generalized linear regression models with gamma distribution and $\log$ link function for the density of bacteria in soil (CFU/ g dry soil), in time, for type of strain for assay and type of soil for assay. For the field assays we fitted a generalized linear regression model with gamma distribution and log link function for the density of bacteria in soil (CFU/g dry soil), in time according to the assay (Nelder and Wedderburn 1972; Diggle et al. 2002). After the fitting, the generalized linear regressions models can be written as: $\hat{E}(Y)=\exp \left(\hat{\beta}_{0}+\hat{\beta}_{1} \cdot\right.$ time $)$, where, $\hat{\mathrm{E}}(\mathrm{Y})$ $=$ is the estimated expected value of the density of bacteria in soil (CFU/g dry soil); $\hat{\beta_{0}}$ and $\hat{\beta_{1}}$ are the estimated parameters and the time is in days. The estimated parameter $\hat{\beta_{1}}$ is related to velocity of decay of the density of bacteria in soil (CFU/g dry soil). We also performed the Spearman correlation between bacterial density, time, humidity, and minimum and maximum temperatures, according to the assay.

\section{Results}

Survival of Curtobacterium flaccumfaciens pv. flaccumfaciens strains in the soil under controlled conditions

There was a difference in the survival period between Cff strains in soil A under controlled conditions, varying from 22 to 34 days (Fig. 1). The strain Feij. 2716C exhibited the shortest and the strain Feij. $2628 \mathrm{~A}$ the longest survival period. Other strains survived for a period from 24 to 32 days at $20{ }^{\circ} \mathrm{C}$. Samples of bacteria recovered in culture medium from each treatment were amplified by PCR using specific-primers to detect Cff, and exhibited positive and negative reaction for bacterial DNA and sterile water, respectively (data not shown).

The velocity of curve decline regarding to the survival period of Cff strains was obtained via the angular coefficient of the fitted lines, with higher negative values indicating the shortest curve decline time and, consequently, the longest time of bacterial survival for strain Feij. 2628A (Table 3).

\section{Survival of Curtobacterium flaccumfaciens pv. flaccumfaciens in different soils under controlled conditions}

There was a difference in the survival period of strain Feij. 2628A in different soils (Fig. 2), varying from 

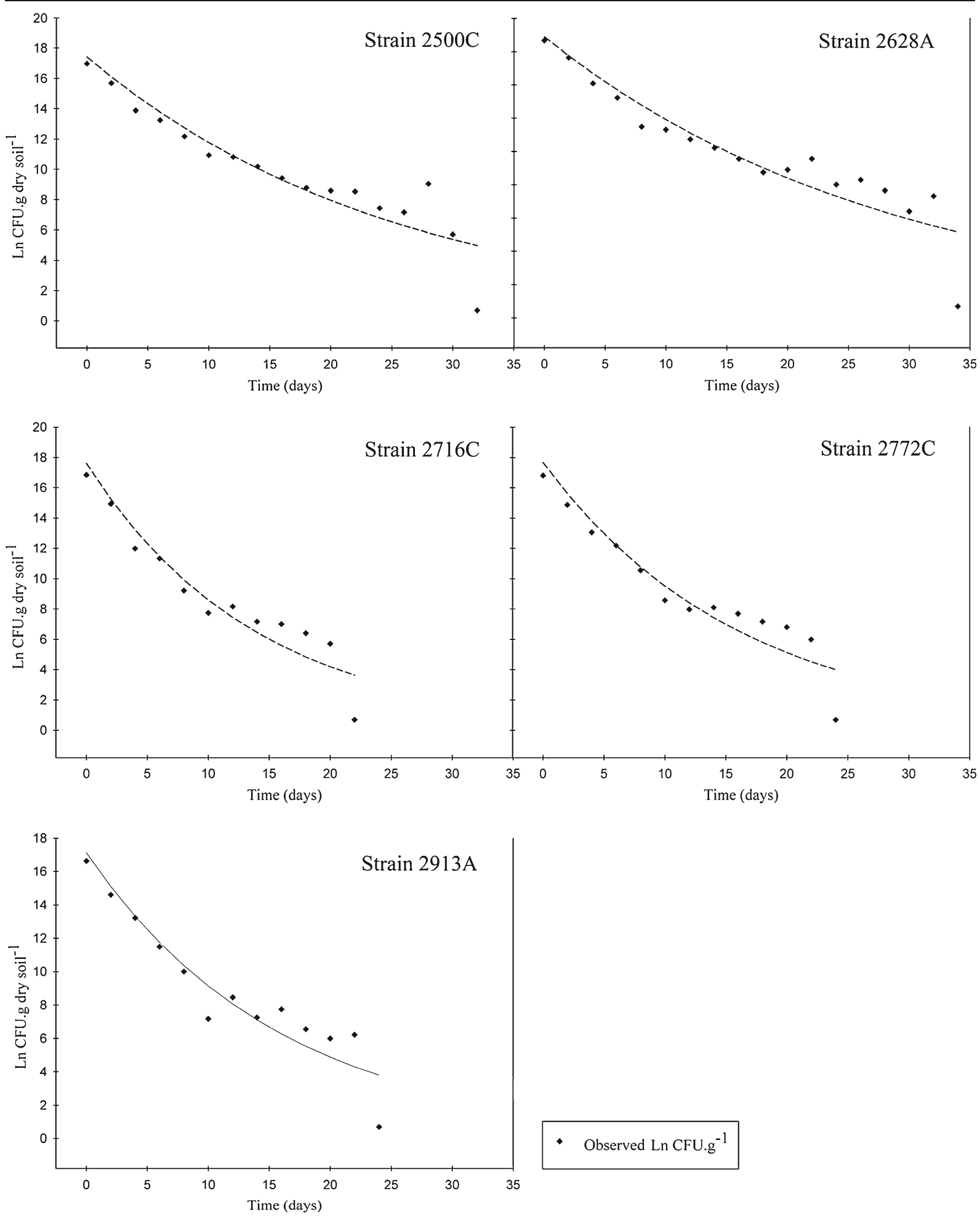

- Observed Ln CFU.g ${ }^{-1}$

Fig. 1 Survival of Curtobacterium flaccumfaciens pv. flaccumfaciens strains under controlled conditions in the soil, in time function

30 days (soil B) to 94 days (soil D) after soil infestation. Soil moisture varied from 15 to $22 \%$. All bacterial samples from each measure were checked by PCR and confirmed the bacteria identity as Cff. 
Table 3 Decay velocity of Curtobacterium flaccumfaciens pv. flaccumfaciens average population $\left(\mathrm{CFU} \mathrm{g} \mathrm{dry} \mathrm{soil}^{-1}\right.$ days $\left.{ }^{-1}\right)$ in soil, following by the $95 \%$ confidence interval, in two assays under controlled conditions

\begin{tabular}{|c|c|c|c|}
\hline Assay $1^{\mathrm{a}}$ & & Assay $2^{b}$ & \\
\hline d.v. $\left(\mathrm{CFU}\right.$ g dry soil ${ }^{-1}$ days $\left.^{-1}\right)$ & Strain & d.v. (CFU g dry soil ${ }^{-1}$ days $\left.^{-1}\right)$ & Soil \\
\hline$-0.3052(-0.3511 ;-0.2593)$ & $2500 \mathrm{C}$ & $-0.1554(-0.1743 ;-0.1364)$ & A \\
\hline$-0.2952(-0.3321 ;-0.2582)$ & $2628 \mathrm{~A}$ & $-0.3620(-0.4186 ;-0.3055)$ & $\mathrm{B}$ \\
\hline$-0.5567(-0.6294 ;-0.4841)$ & $2716 \mathrm{C}$ & $-0.0982(-0.1222 ;-0.0742)$ & $\mathrm{C}$ \\
\hline$-0.4856(-0.5469 ;-0.4243)$ & $2772 \mathrm{C}$ & $-0.1108(-0.1239 ;-0.0977)$ & $\mathrm{D}$ \\
\hline \multirow[t]{2}{*}{$-0.4822(-0.5472 ;-0.4173)$} & 2913A & $-0.1655(-0.1797 ;-0.1513)$ & $\mathrm{E}$ \\
\hline & & $-0.1234(-0.1336 ;-0.1132)$ & $\mathrm{F}$ \\
\hline
\end{tabular}

${ }^{\mathrm{a}}$ The survival period of five strain was assessed in soil A

${ }^{\mathrm{b}}$ The survival period of strain Feij. 2628A was assessed in six different soils

The velocity of curve decline indicates that soils C, D and $\mathrm{F}$ (higher negative values of angular coefficient) were the soils in which strain Feij. 2628A survived for the longest period; soil $\mathrm{B}$ exhibited a higher decline velocity (Table 3).

Survival of Curtobacterium flaccumfaciens pv. flaccumfaciens in soil under field conditions

The survival period of Cff in soil was 46, 34, and 80 days, respectively, for assays 1, 2, and 3 (Fig. 3). Bacterial samples from each measure were confirmed as Cff by PCR.

Climatic data obtained during the three assays are described in Table 4. Accumulated precipitations were $223.2,113.4$, and $134.2 \mathrm{~mm}$, respectively, in assays 1,2, and 3. During 15 days after soil infestation, accumulated precipitation was 90.4, 70.9, and $12.9 \mathrm{~mm}$ in assays 1,2 , and 3 , respectively. Within 30 first days, the accumulated precipitation was 131.8 in assay $1,112.6$ in assay 2, and $22.8 \mathrm{~mm}$ in assay 3 . After 45 days, accumulated precipitation was 205.9 and $58.2 \mathrm{~mm}$ in assays 1 and 3, respectively. In assay 3, the accumulated precipitation was 70.1 at 60 days and $134.2 \mathrm{~mm}$ at 75 days. Average temperature during the entire survival period was 18.5, 24.9, and $19.2{ }^{\circ} \mathrm{C}$, respectively, in assay 1,2 , and 3 .

The velocity of curves decline was influenced by the climatic factors maximum temperature and moisture (Table 5). Assay 3 exhibited a higher angular coefficient value of the fitted lines, but no significant values for the influence of climatic factors (Table 5).

\section{Discussion}

RifR variants of Cff selected from the Bacterial Collection exhibit naturally occurring resistance to the antibiotic, contributing to Cff recovery from the sample soil with high-biodiversity. All Cff resistant strains were phytopathogenic to common bean (data not shown). Differences observed among strains were colony colour and origin of isolation. In present study, we did not evaluate the influence of climatic conditions as temperature and moisture under controlled conditions because Cff survival period were already know to be influenced by these factors (Silva Júnior et al. 2012), and for these reasons we standardized the temperature at $20^{\circ} \mathrm{C}$ and adjusted the moisture between 15 and $22 \%$ for assays under controlled conditions, factors levels that Cff shown longest survival period by Silva Júnior et al. (2012). In the same work, was observed survival period of seven mutants from one strain of Cff as free cells in soil varying from two and 16 days. The present study is the first observation of variation in the survival period of different strains of Cff as free cells in Brazilian soil.

Cff survived for the longest period in soil D, which had a clayey texture. According to earlier studies, bacteria survived for longer periods, under lower moisture levels, inside of clayey aggregates in relation to the external side, possibly due to the higher water availability inside the aggregates (Hattori 1973); this could explain the lower survival period in soil A with sandy texture. There are reports that the clayey aggregates form an envelope around bacterial cells, caused by electrostatic attraction between charged groups on the clay surface and bacteria, protect the cells against 

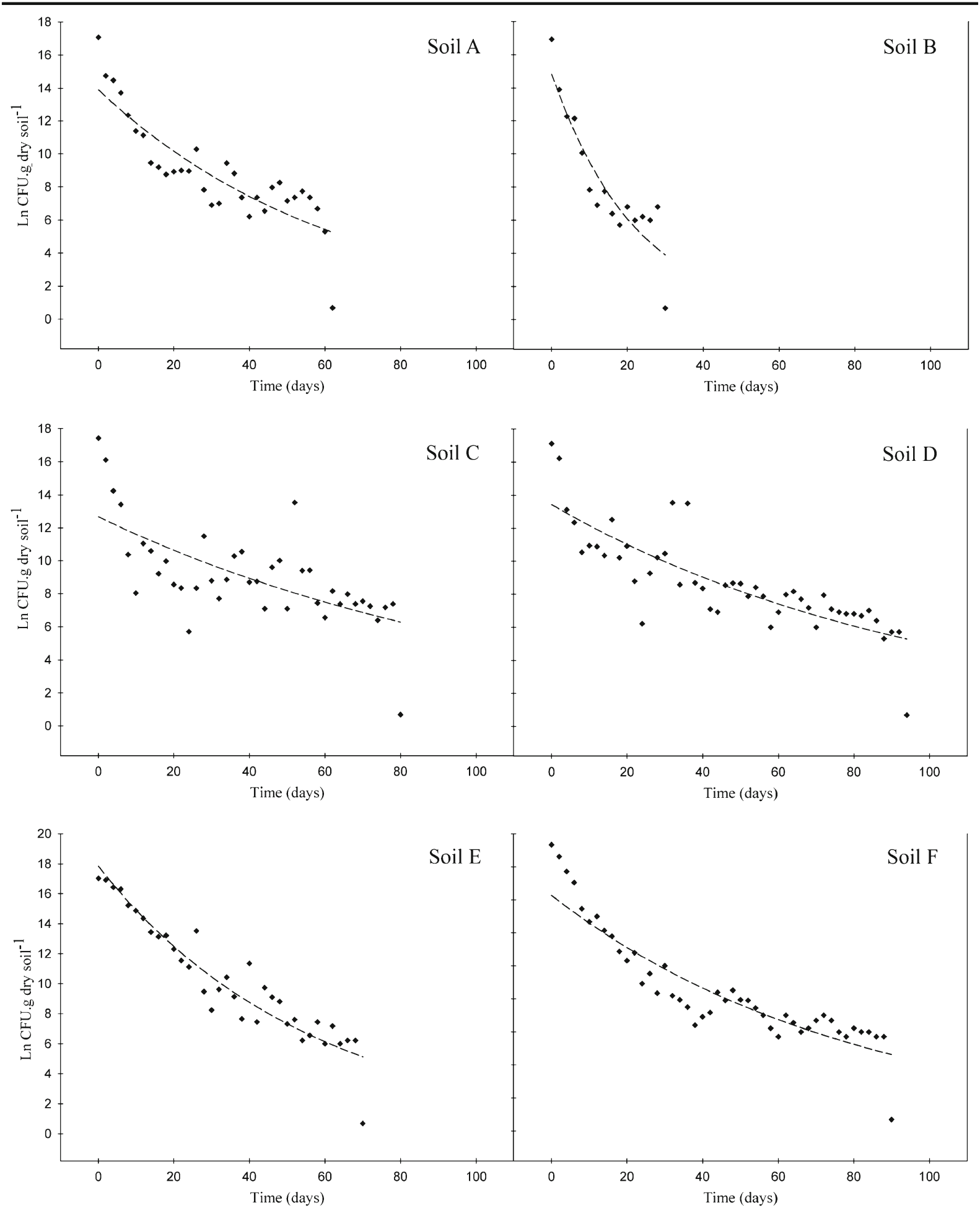

- Observed Ln CFU.g ${ }^{-1}$

Fig. 2 Survival of Feij. 2628A strain of Curtobacterium flaccumfaciens pv. flaccumfaciens under controlled conditions in six different soils, in time function 

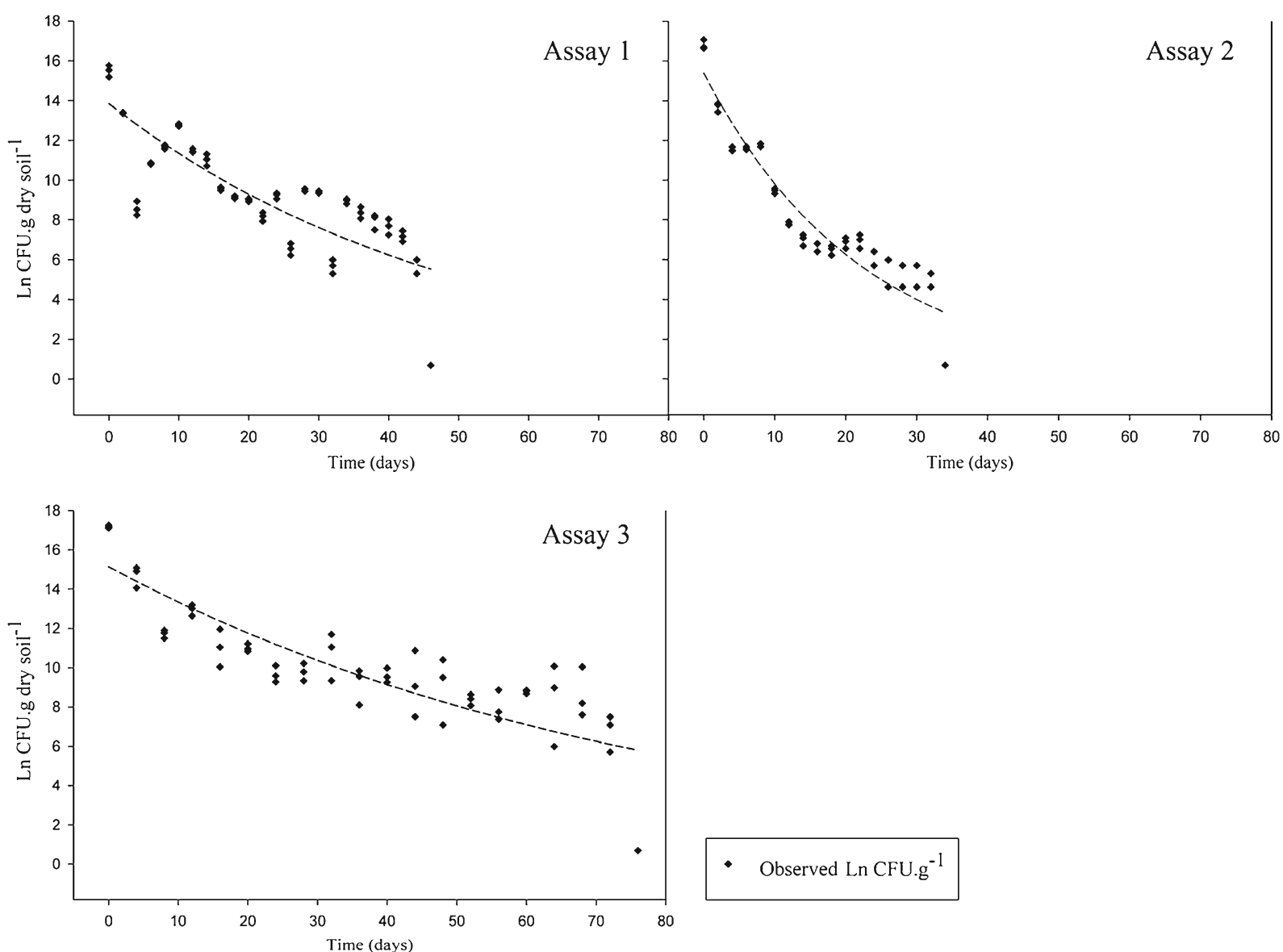

- Observed Ln CFU.g ${ }^{-1}$

Fig. 3 Survival of Feij. 2628A strain of Curtobacterium flaccumfaciens pv. flaccumfaciens under field conditions in the soil in time function: assay 1 (installation at 16/05/2013); assay $2(20 / 12 / 2013)$ and assay $3(22 / 07 / 2014)$

desiccation and rehydration (Marshall 1971). Soils enriched with organic matter tend to have higher numbers of antagonistic microorganisms (Schuster and Coyne 1974); however, in this work, we could not observe an interference of soil organic matter levels with the Cff population. Soil A was selected to be used in assays under controlled conditions due the lowest concentration of organic matter, which could be correlated with lowest antagonistic microorganism populations, eliminating the moisture factor in sandy soil texture, monitoring and maintaining the level within the range $15-22 \%$.

Climatic factors confirmed to have an influence on Cff survival period, especially precipitation and maximum temperature, as free cells in soil under field conditions. In assay 3 , the longest survival period could be explained by the unfavorable climatic conditions for antagonistic microbial populations responsible for antibiotics production (Schuster and Coyne 1974). Soil moisture directly interferes with the antagonistic microflora, such as protozoa, actinobacteria, bacteria, fungi, and nematodes (Schuster and Coyne 1974). The survival of Xanthomonas citri pv. fuscans in common bean leaflets varied from 65 to 180 days and from 30 to 120 days when placed on the soil surface and buried at a depth of $15 \mathrm{~cm}$, respectively, under mild temperatures and low rainfall (Torres et al. 2009). In the same work, survival period was influenced by higher rainfall and temperatures, decreasing the average period by about $50 \%$. The survival period of $X$. campestris pv. viticola in crop debris in the soil was influenced by temperature (increasing temperatures negatively influenced the bacterial population in soil), and by antagonistic activities of Acinetobacter calcoaceticus, Paenibacillus lentimorbus, Paenibacillus macerans, Bacillus megaterium, Aspergillus fumigatus, Emericella nidulans, and E. nidulans var. acristata (Silva et al. 2012). 
Table 4 Climatic data of average temperature $\left({ }^{\circ} \mathrm{C}\right)$ and sum of precipitation $(\mathrm{mm})$ in intervals of five days from the moment of assays installation to study population dynamic of Curtobacterium flaccumfaciens pv. flaccumfaciens under field conditions

\begin{tabular}{|c|c|c|c|c|c|c|}
\hline \multirow[t]{2}{*}{ Interval } & \multicolumn{2}{|l|}{ Assay 1} & \multicolumn{2}{|l|}{ Assay 2} & \multicolumn{2}{|l|}{ Assay 3} \\
\hline & $\begin{array}{l}\text { Average temperature } \\
\left({ }^{\circ} \mathrm{C}\right)\end{array}$ & $\begin{array}{l}\sum \text { of precipitation } \\
(\mathrm{mm})\end{array}$ & $\begin{array}{l}\text { Average temperature } \\
\left({ }^{\circ} \mathrm{C}\right)\end{array}$ & $\begin{array}{l}\sum \text { of precipitation } \\
(\mathrm{mm})\end{array}$ & $\begin{array}{l}\text { Average temperature } \\
\left({ }^{\circ} \mathrm{C}\right)\end{array}$ & $\begin{array}{l}\Sigma \text { of precipitation } \\
(\mathrm{mm})\end{array}$ \\
\hline $0-5$ & 21,2 & 0,0 & 24 & 16,3 & 18,0 & 12,9 \\
\hline $6-10$ & 19,3 & 9,5 & 26,5 & 26,0 & 16,1 & 0,0 \\
\hline $11-15$ & 16,9 & 80,9 & 24,5 & 28,6 & 20,1 & 0,0 \\
\hline $16-20$ & 17,2 & 27,5 & 25,5 & 5,3 & 17,5 & 0,0 \\
\hline $21-25$ & 18,9 & 0,0 & 25,2 & 28,5 & 17,8 & 8,6 \\
\hline $26-30$ & 19,2 & 13,9 & 23,7 & 7,9 & 18,2 & 1,3 \\
\hline $31-35$ & 17,4 & 18,7 & 24,9 & 0,8 & 22,1 & 0,0 \\
\hline $36-40$ & 15,9 & 11,9 & - & - & 18,8 & 0,0 \\
\hline $41-45$ & 18,1 & 43,5 & - & - & 19,0 & 35,4 \\
\hline $46-50$ & 21,2 & 17,3 & - & - & 19,9 & 0,0 \\
\hline $51-55$ & - & - & - & - & 22,8 & 0,0 \\
\hline $56-60$ & - & - & - & - & 20,5 & 11,9 \\
\hline $61-65$ & - & - & - & - & 19,8 & 13,8 \\
\hline $66-70$ & - & - & - & - & 19,7 & 44,0 \\
\hline $71-75$ & - & - & - & - & 18,2 & 6,3 \\
\hline $76-80$ & - & - & - & - & 18,6 & 0,0 \\
\hline Total & 18,5 & 223,2 & 24,9 & 113,4 & 19,2 & 134,2 \\
\hline
\end{tabular}

Bacteria of the genus Curtobacterium usually do not survive for long periods as free cells in soil, but could overwinter in the soil (Schuster and Coyne 1974). Like most bacteria, Cff does not produce endospores as resistant structures. However, Cff is resistant to dehydration and can remain viable for 24 years in common bean seeds stored in the laboratory (Burkholder 1945). Under field conditions, it could survive in the soil for at least two consecutive winters in common bean crop rotated with wheat (EPPO/CABI 1997). In Brazil, Cff survived for up to 240 days in crop debris of common bean kept on the soil surface, but the survival period decreased to 30 days when debris was incorporated at a depth of $20 \mathrm{~cm}$ (Silva Júnior et al. 2012). In the same work, authors inferred that soil moisture level and temperature during the incubation period could favor the increase of the antagonistic microorganism population responsible for the production of antibiotics, which decrease or inhibit the Cff population in the soil. In the present study, biodiversity of bacteria and fungi were observed in negative control samples, but these microorganisms were not identified and antagonistic microorganism

Table 5 Decay velocity of Curtobacterium flaccumfaciens pv. flaccumfaciens population (CFU g dry soil ${ }^{-1}$ days $^{-1}$ ) in soil, following by the $95 \%$ confidence interval, and its Spearman correlation with climatic conditions, in three assays under field conditions

\begin{tabular}{|c|c|c|c|c|}
\hline \multirow[t]{2}{*}{ Assay } & \multirow[t]{2}{*}{ d.v. (CFU g dry soil ${ }^{-1}$ days $\left.{ }^{-1}\right)$} & \multicolumn{3}{|c|}{ Spearman Correlations ${ }^{(*)}$ (Cff population $\mathrm{x}$ climatic conditions) } \\
\hline & & Max. T. & Min. T. & Humidity \\
\hline 1 & $-0.0200(-0.0260 ;-0.0139)$ & N.S. & N.S. & -0.28100 \\
\hline 2 & $-0.0450(-0.0535 ;-0.0365)$ & 0.38115 & N.S. & N.S. \\
\hline 3 & $-0.0126(-0.0169 ;-0.0083)$ & N.S. & N.S. & N.S. \\
\hline
\end{tabular}

N.S. non significant

${ }^{*} p<0.05$ 
activity was not evaluated. These factors provide a hypothesis to negatively interfere in Cff population. Even for Cff strain surviving for the longest period in the soil D, antagonistic activity may contribute to understanding the differences of Cff survival period among clayey soils.

Based on our results, Cff can survive as viable free cells in the soil at low concentrations, requiring more attention in the management of bacterial wilt in common bean cultivation. We therefore suggest rotation with non-hosts of the bacterium to minimize the risk of primary inoculum or incorporation of common bean debris, with a fallow period for at least one year.

Acknowledgements The authors thank the Coordenação de Aperfeiçoamento de Pessoal de Nível Superior (CAPES) for the granting of the doctoral scholarship for the first author.

\section{Compliance with ethical standards}

Conflict of interest The authors declare that they have no conflict of interest.

\section{References}

Burkholder, W. H. (1945). The longevity of the pathogen causing the wilt of the common bean. Phytopathology, 35(9), 743744.

Collins, M. D., \& Jones, D. (1983). Reclassification of Corynebacterium flaccumfaciens, Corynebacterium betae, Corynebacterium oortii and Corynebacterium poinsettiae in the genus Curtobacterium, as Curtobacterium flaccumfaciens comb. nov. Microbiology, 129(11), 35453548. https://doi.org/10.1099/00221287-129-11-3545.

De Boer, S. H. (1982). Phytopathogenic prokaryotes. In M. S. Mount \& G. H. Lacy (Eds.), (pp. 285-305). New York, USA: Academic Press.

Diggle, P., Heagerty, P., Liang, K., \& Zeger, S. (2002). Analysis of longitudinal data. Oxford: Oxford University Press.

EPPO/CABI. (1997). Curtobacterium flaccumfaciens pv. flaccumfaciens. In Quarantine Pests for Europe (2nd ed., pp. 991-994). Wallingford: CAB International. https://www.eppo.int/QUARANTINE/data sheets/bacteria/CORBFL_ds.pdf.

Gonçalves, R. M., Schipanski, C. A., Koguishi, L., Soman, J. M., Sakate, R. K., Júnior, T. A. F. S., \& Maringoni, A. C. (2017). Alternative hosts of Curtobacterium flaccumfaciens pv. flaccumfaciens, causal agent of bean bacterial wilt. European Journal of Plant Pathology, 148(2), 357-365. https://doi.org/10.1007/s10658-016-1094-4.
Harveson, R. M. (2013). The multicolored bacterium. APSnet Feature Article. https://doi.org/10.1094/APSFeature-201311

Harveson, R. M., Vidaver, A. K., \& Schwartz, H. F. (2005). Bacterial wilt of dry beans in western Nebraska. Cooperative Extension: Institute of Agriculture and Natural Resources, University of Nebraska-Lincoln.

Hattori, T. (1973). Microbial life in the soil; an introduction. New York: M. Dekker.

Leben, C. (1981). How plant-pathogenic bacteria survive. Plant Disease, 65(8), 633-637.

Lennon, J. T., Aanderud, Z. T., Lehmkuhl, B. K., \& Schoolmaster, D. R. (2012). Mapping the niche space of soil microorganisms using taxonomy and traits. Ecology, 93(8), 1867-1879. https://doi.org/10.1890/11-1745.1.

Marshall, K. C. (1971). Sorptive interactions between soil particles and microorganisms. Soil. Biochemistry, 2, 409-445.

Nelder, J. A., \& Wedderburn, R. W. M. (1972). Generalized linear models. Journal of the Royal Statistical Society. Series A (General) Journal of the Royal Statistical Society. Series A General J. R. Statist. Soc. A, 13517213(3), 370-384.

Osdaghi, E. (2014). Bacterial wilt of lima bean (Phaseolus lunatus) caused by Curtobacterium flaccumfaciens pv. flaccumfaciens, a new disease in Iran. Journal of Plant Pathology, 96(4SUP), 4-118. https://doi.org/10.4454/JPP. V96I4.021.

Osdaghi, E., Taghavi, S. M., Hamzehzarghani, H., Fazliarab, A., Harveson, R. M., Tegli, S., \& Lamichhane, J. R. (2017). Epiphytic Curtobacterium flaccumfaciens strains isolated from symptomless solanaceous vegetables are pathogenic on leguminous but not on solanaceous plants. Plant Pathology. https://doi.org/10.1111/ppa.12730.

Sammer, U. F., \& Reiher, K. (2012). Curtobacterium flaccumfaciens pv. flaccumfaciens on soybean in Germany a threat for farming. Journal of Phytopathology, 160(6), 314316. https://doi.org/10.1111/j.1439-0434.2012.01902.x.

Schuster, M. L., \& Coyne, D. P. (1974). Survival mechanisms of phytopathogenic bacteria. Annual Review of Phytopathology, 12(1), 199-221. https://doi.org/10.1146/annurev. py.12.090174.001215.

Silva Júnior, T. A. F., Negrão, D. R., Itako, A. T., Soman, J. M., \& Maringoni, A. C. (2012). Survival of Curtobacterium flaccumfaciens pv. flaccumfaciens in soil and bean crop debris. Journal of Plant Pathology, 94(2), 331-337. https://doi.org/10.4454/JPP.FA.2012.025.

Silva, A. M. F., Menezes, E. F., Souza, E. B., Melo, N. F., \& Mariano, R. L. M. (2012). Survival of Xanthomonas campestris pv. viticola in infected tissues of grapevine. Revista Brasileira de Fruticultura, 34, 757-765.

Tegli, S., Sereni, A., \& Surico, G. (2002). PCR-based assay for the detection of Curtobacterium flaccumfaciens pv. flaccumfaciens in bean seeds. Letters in Applied Microbiology, 35(4), 331-337.

Torres, J. P., Maringoni, A. C., \& Silva Jr, T. A. F. (2009). Survival of Xanthomonas axonopodis pv. phaseoli var. fuscans in common bean leaflets on soil. Journal of Plant Pathology, 195-198.

Vidaver, A. K., \& Lambrecht, P. A. (2004). Bacteria as plant pathogens. The Plant Health Instructor. https://doi. org/10.1094/PHI-I-2004-0809-01. 
Weller, D. M., \& Saettler, A. W. (1978). Rifampin-resistant Xanthomonas phaseoli var. fuscans and Xanthomonas phaseoli: Tools for field study of bean blight bacteria. Phytopathology, 68(5), 778-781.
Wilson, K. (2001). Preparation of Genomic DNA from Bacteria. In Current Protocols in Molecular Biology (Vol. Chapter 2, p. Unit 2.4). Hoboken, NJ, USA: John Wiley \& Sons, Inc. https://doi.org/10.1002/0471142727.mb0204s56. 